\title{
Co-occurrence between macrophytes and macroinvertebrates: towards a new approach for the running waters quality evaluation?
}

\author{
Lorenzo TRAVERSETTI,${ }^{1 *}$ Simona CESCHIN,${ }^{1}$ Alessandro MANFRIN,${ }^{2}$ Massimiliano SCALICI ${ }^{1}$ \\ ${ }^{1}$ Department of Sciences, University of Roma Tre, Viale G. Marconi 446, 00146 Rome, Italy; ${ }^{2}$ Leibniz Institute of Freshwater Ecology \\ and Inland Fisheries (IGB), Müggelseedamm 301, 12587 Berlin, Germany \\ *Corresponding author: lorenzo.traversetti@uniroma3.it
}

\begin{abstract}
Several studies on concordance between macrophyte and macroinvertebrate communities were carried out for decades while any investigation on co-occurrence of single pair of taxa of these two groups was never addressed. Our main aim was to verify the existence of co-occurrence of single macrophyte-macroinvertebrate pair in a Mediterranean river of central Italy. We compared the co-occurrence frequencies of different plant and animal taxa with those expected by chance through the null model approach. Specifically, we proposed two main co-occurrence patterns of macrophyte and macroinvertebrate taxa in terms of aggregation (when groups co-occur more frequently than expected) and segregation (when groups co-occur less frequently than expected). This approach was supported by correlations and analysis of covariance in order to identify the most significant co-occurring pairs. In this study we collected a total of 123 taxa (50 macrophytes +73 macroinvertebrates) in October 2008 and 102 (42+60) in June 2009. We obtained a total of 379 significantly correlating macrophyte-macroinvertebrate pairs. Amongst all these correlating pairs, $83.7 \%$ of them correlated in October session while $90.3 \%$ in June. All the correlating pairs showed a high relationships with human alterations in both the sampling sessions. Our results confirmed that direct correlations there are between macrophytes and macroinvertebrates, highlighting how these two biological groups co-occur mainly following the aggregative model in both sampling sessions. Therefore, it was possible to observe significant relationships between macrophyte and macroinvertebrate pairs along an entire river ecosystem. It allows us to demonstrate that there are some prospective for trying to increase the knowledge on macrophytes-macroinvertebrates co-occurrence and for suggesting to use only single pair of co-occurring taxa in the monitoring running water quality. Aware that more investigations ought to be performed for confirming our proposal, the findings of the present study may be suggested as a new monitoring tool since it represents an investigation approach easy in the application, feasible and rapid in the execution, and within the European Water Framework Directive freshwater management policies. In addition, a such tool does not need a detailed taxonomical expertise since its applicability is restricted only to the few taxa indicated as representatives of a certain water quality condition.
\end{abstract}

Key words: Aquatic plant, aquatic invertebrate, assemblage structure, null models, central Italy.

Received: March 2014. Accepted: August 2014.

\section{INTRODUCTION}

Human alteration represents today a well-known phenomenon of disturbance mainly for freshwater habitats (Dynesius and Nilsson, 1994; Malmqvist and Rundle, 2002; Dudgeon et al., 2006). Land-use and urban development are responsible for altering species composition, food web structure, nutrient cycling, and ecosystem functioning (Johnes, 1996; Wootton et al., 1996; Jansson et al., 2000; Vörösmarty et al., 2000). This seems to be particularly worrying for catchments within semi-arid regions, such as a Mediterranean one (Hermoso et al., 2010).

The more and more detrimental condition of the river habitats stimulated the European Community to propose new guidelines for the aquatic monitoring by issuing the Water Framework Directive (WFD; European Council, 2000). Among the main goals of the WFD is to propose a new river monitoring system based on an integrated biological assessment by using different taxonomic groups
(Hering et al., 2006). Within the WFD line, several studies on concordance of assemblages amongst different aquatic taxa (diatoms, macrophytes, macroinvertebrates, fishes) were carried out (Hering et al., 2004; Heino, 2010; Larsen et al., 2012; Traversetti et al., 2013; Mazzini et al., 2014). A such data collection, although useful and functional, needs a great effort in terms of fund, time, and expertise. Therefore further approaches ought to be promoted as the WFD suggested. In this context, investigations on co-occurrence of single pairs of macrophyte and macroinvertebrate taxa (hereafter called pairs) may represent an alternative way in the river monitoring activities.

Here we propose for the first time a new viewpoint based on the co-occurrence of the single pairs to provide new water quality descriptors. Then we investigate the cooccurrence between pairs at level of taxon (and not at community) in terms of aggregation and/or segregation by the null model approach (Gotelli, 2000). Null models represent one of the most effective ways to test patterns 
of taxa co-occurrence in a community (Gotelli, 2000). Although the use of this method was debated in the past (Colwell and Winkler, 1984), to date it seems provide important information on taxa co-occurrence patterns. In addition, despite some aspects of the algorithms suggested by Gotelli (2000) and Gotelli and Entsminger (2001) have been criticized (Sanderson, 2000; Hausdorf and Hennig, 2007), their good statistical properties have been demonstrated (Gotelli, 2000; Gotelli and McCabe, 2002), leading to a substantial increase in community studies in the last decade (Krasnov et al., 2006, 2010; Dörr et al., 2012). Specifically, in the null model approach, the observed frequency of co-occurring species in a natural community is compared with a set of simulated communities with randomly generated species assemblages. Briefly, if species co-occur more often than expected by chance the assemblage is structured aggregately, throughout interspecific facilitation or shared preferences (Krasnov et al., 2006). When species co-occur less frequently than expected by chance, the assemblage is structured segregatively, mainly due to competition or different microhabitat preferences.

Our study is aimed to i) verify the co-occurrence pattern between macrophytes and macroinvertebrates, and ii) demonstrate a grade of non-randomness for specific pairs. Possible reflections on running water monitoring activities and river status evaluation are discussed in the last section.

\section{METHODS}

\section{Study area and data collection}

We collected both macrophytes and macroinvertebrates in the same $50 \mathrm{~m}$ length river segment of 11 sites of the River Aniene (central Italy, Fig. 1). Sites were dis- tributed along the whole river from the source to its confluence within the River Tiber and are separated by no less than $8 \mathrm{~km}$, according to Lloyd et al. (2006). This river could be subdivided into three sections. Particularly it flow within highly natural areas characterized by woodlands and pastures (sites A-C) in the first section. The second (sites D-G) is characterized by the presence of rare anthropic activities and structures like agriculture and roads, this structures increasing in the last section (sites $\mathrm{H}-\mathrm{K}$ ), when the river flow within some towns, Rome inclusive (site K). The samplings were carried out according to the national protocols of sampling for macrophytes (APAT, 2007) and macroinvertebrates (CNR-IRSA, 2007). Both protocols were partially modified for a better local adaptation of the sampling procedures (Ceschin et al., 2010; Larsen et al., 2012; Manfrin et al., 2013; Traversetti and Scalici, 2014). In order to assess eventual seasonal differences in the macrophyte-macroinvertebrate assemblage, each site was sampled twice: in October 2008 and June 2009. For the macrophyte collection, at each sampling site, we listed all species with their coverage value according to the Braun-Blanquet (1964): + , sporadic species; 1 , species with coverage $<5 \% ; 2,5-25 \% ; 3,25$ $50 \% ; 4,50-75 \% ; 5,>75 \%$.

Different collection methods were used for each macrophyte group: floating masses of filamentous macroalgae were collected by means of a $25 \mu \mathrm{m}$ mesh plankton net; epilithic macroalgae and cyanobacteria by scraping stones; bryophytes from boulders and cobbles in the riverbed and along the riverbanks by scalpel; vascular plants by direct observation in situ or collection of samples using a grappling iron. All macroalgae and cyanobacteria were fixed in formalin (approximately 4\% final concentration). Taxo-

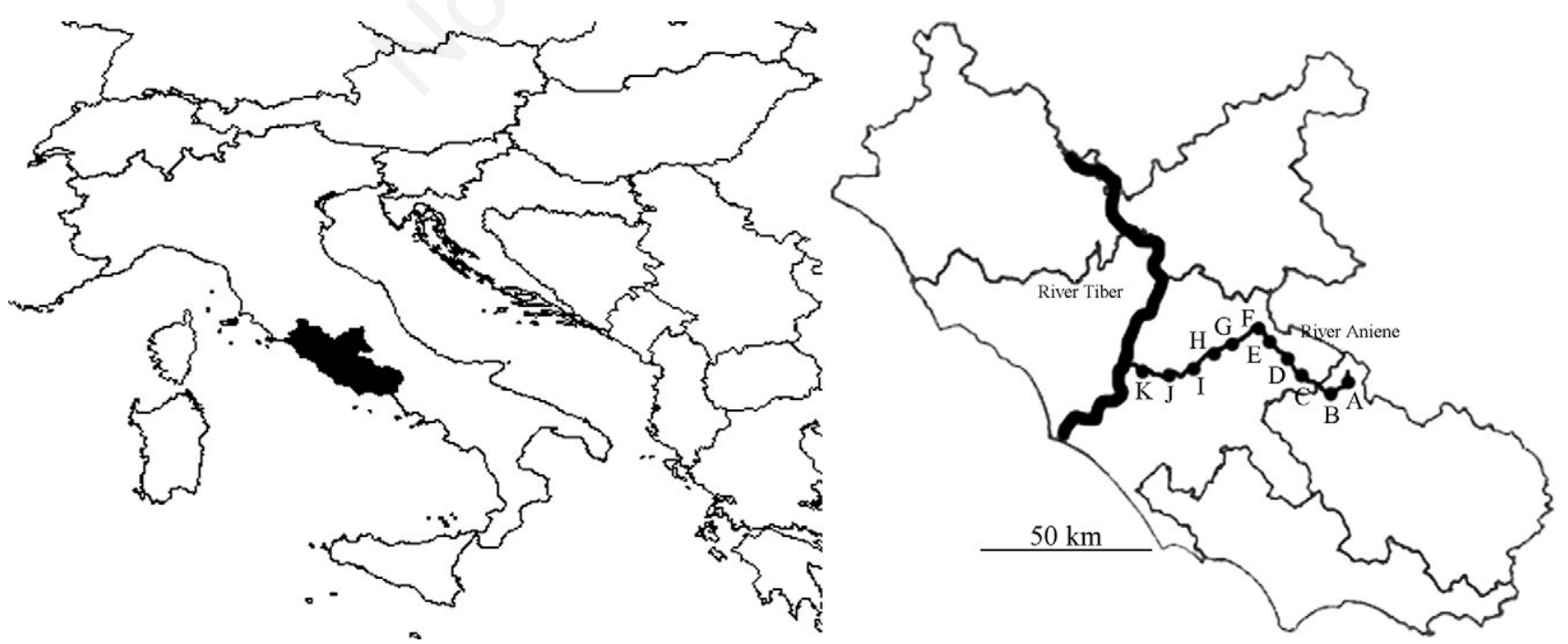

Fig. 1. Location of the sampling sites within the study area. A, Filettino; B, Trevi nel Lazio; C, Jenne; D, Subiaco; E, Madonna della Pace; F, Anticoli Corrado; G, Vicovaro; H, Castel Madama; I, Tivoli; J, Lunghezza; K, Roma Nomentana. 
nomical determination and nomenclature were based on scientific literature and taxonomic guides by John et al. (2002), Bourrelly (1981, 1985, 1990), and Ettl and Gärtner (1995) for algae and cyanobacteria, Cortini Pedrotti (2001, 2005) and Aleffi et al. (2008) for bryophytes, Pignatti (1982) and Conti et al. (2005) for vascular plants. The macroinvertebrate collection was performed only in riffles following the multi-habitat scheme (Buffagni et al., 2005). A microhabitat was sampled when it covered at least $10 \%$ of the investigated portion of the riverbed (Supplementary Tab. 1). A total of 10 sample units (reach) were collected in each site by using a Surber sampler (area $0.05 \mathrm{~m}^{2}$; mesh size $0.5 \mathrm{~mm}$ ) by a standard collection protocol just performed in central Italy (Pace et al., 2011). Macroinvertebrates were grossly sorted in field, preserved with $95 \%$ ethanol, and then identified in laboratory to family level (except for Trichoptera and Plecoptera at genus, and Ephemeroptera at species), such as the most fine level based on literature and available taxonomic guides (Consiglio, 1980; Belfiore, 1983; Moretti, 1983; Sansoni, 1988; Campaioli et al., 1999). The most representative macrophyte and macroinvertebrate specimens are deposited at the Herbarium and the Museum of Comparative Anatomy and Zoology of University of Roma Tre.

\section{Analysis design}

According to the Dörr et al. (2012) protocol, we provided a way of testing patterns of co-occurring pairs within a community by comparing the observed frequencies of cooccurrences of macrophytes and macroinvertebrates along the upstream-downstream trend (i.e., across the river sites) with those expected by chance. To quantify structure patterns of the macrophyte and macroinvertebrate assemblages, we organized a single presence-absence (1-0) data matrix (McCoy and Heck, 1987), where each row represents a river sampling site while each column a taxon.

After the matrix organization, we calculated the two indices C-score (checkerboard score, sensu Stone and Roberts, 1990) and V-ratio (variance ratio, sensu Schluter, 1984) which are single numbers measuring patterns for an entire presence/absence matrix. C-score is calculated as the average number of the matrix squares (i.e., checkerboard units) that are found for each pair of taxa (i.e., indicating the co-presence of the two taxa). In a competitively structured community, the C-score should be significantly larger than expected by chance (Gotelli, 2000). The V-ratio is the ratio between the variance in taxa richness and the sum of the variance in taxa occurrence. When the value of the ratio equals 1 , taxa are distributed independently. It is smaller or greater than 1 in the case of negative or positive covariance between pairs, respectively (Gotelli, 2000).

We used both indices based on two different matrix structures (namely average co-occurrence and average co- variance, respectively) because they have shown to be statistically powerful and robust to minor changes in community structure (Gotelli, 2000). Mathematical and statistical details, and properties and performance in null model tests of the metrics can be found in Gotelli and Rohde (2002) and Krasnov et al. (2006, 2010). The Vratio was calculated both including and excluding checkerboard units without the investigated taxa from the presence-absence matrix (WI, with empty checkerboard units; WO, without empty checkerboard units) to investigate their effect on the results (Gotelli and Rohde, 2002). Since they may potentially affect the null model analyses, we choose to study both models and to examine their effect on this analysis. Empty sites may be interpreted in two ways: 1) sampling sites not available for colonization; 2) sampling sites exploitable but not colonized by chance.

For each matrix we compared the observed index $(\mathrm{O})$ with that simulated by 999 Monte Carlo random permutations [i.e., expected (E) by chance] (Gotelli and Entsminger, 2001). This number of permutations ensures that algorithm biases are avoided (Lehsten and Harmand, 2006). Observing a $\mathrm{C}$-score value to be smaller than expected by chance $\left(\mathrm{O}_{\mathrm{C}}<\mathrm{E}_{\mathrm{C}}\right)$ means aggregation of taxa. In this case we expect that the $\mathrm{V}$-ratio is larger than expected by chance $\left(\mathrm{O}_{\mathrm{V}}>\mathrm{E}_{\mathrm{V}}\right)$. On the contrary, when taxa show segregation, we expect the $\mathrm{C}$-score to be larger and the V-ratio to be smaller than expected by chance $\left(\mathrm{O}_{\mathrm{C}}>\mathrm{E}_{\mathrm{C}}, \mathrm{O}_{\mathrm{V}}<\mathrm{E}_{\mathrm{V}}\right)$ (Gotelli and Rohde, 2002). Non-random differences were assumed setting always $\alpha=0.05$ (Gotelli and Graves, 1996). We used two null algorithms for each comparison: fixed-fixed ( $f f$ ) and fixedequiprobable $(f e)$. The $f f$ null model treats the empty units of the matrices as unusable, whereas the $f e$ null model treats the empty units as random absences. In the fe null model, empty units in the real data sets may be occupied in the null communities, whereas in the ff null model, empty units in the real data sets remain empty in the null communities. The $f f$ algorithm maintains the differences among units in the number of investigated taxa. Differently, the $f e$ algorithm does not constrain the number of taxa that inhabits a site. This last model suggests no differences in the probability to support a particular number of macrophytes and macroinvertebrates among sampling sites. This statistic approach cannot be used for V-ratio because the latter is determined by marginal totals of the matrix rather than by taxa co-occurrence pattern (Gotelli, 2000). So we used both these algorithms only for C-score. All tests performed for evaluating the macrophyte-macroinvertebrate co-occurrence were carried out for the two sampling sessions separately (October 2008 and June 2009). Since the null models did not show what are the pairs participating to the nonrandomness, we performed a series of Spearman's correlations (setting $\alpha=0.05$ ) by using data on abundances across site for both macrophytes and macroinvertebrates in order to identify the plant-animal pairs participating to the co-oc- 
currence. Also in this case, analyses were performed per sampling session separately.

Once performed all the correlation tests, we carried out an analysis of covariance (ANCOVA) per sampling session for demonstrating that the investigated pairs may provide information on the environmental status. To do so, we attributed a value ranging from 1 (very sensitive) to 5 (very tolerant) to the correlating taxa on the base of the sensitivity classes (see below) (Tabs. 1 and 2). The sensitivity grade to human alterations (i.e., water pollution and hydromorphological alterations) was defined exploiting information from literature (Tachet et al., 2002; AFNOR, 2003) and depending on the authors' expertise. In particular, we inserted each collected taxon in one of five sensitivity classes, proposed as follows: i) very sensitive; ii) sensitive; iii) generalist (taxa with wide ecological behaviour); iv) tolerant; v) very tolerant.

ANCOVA was performed using the mean sensitivity class values of pairs per site as dependent variables, the sampling sites as independent categorical variable, and the anthropogenic index (AI) as covariate. AI was calculated on the basis of land use information for a $1 \mathrm{~km}$ radius around each site as follows:

$$
\mathrm{AI}=\sum \mathrm{k}_{\mathrm{i}} \mathrm{p}_{\mathrm{i}}
$$

where $k_{i}$ is the specific coefficient for each land-use category and $p_{i}$ is the relative frequency of each category inside the $1-\mathrm{km}$ buffer. The following $\mathrm{k}$ values were attributed to the respective CORINE land use categories: 1, natural woods; 2, pastures, meadows, bush areas, scrub and olive grove; 3, agricultural areas and urban green areas; 4, urban and industrial areas. The $1 \mathrm{~km}$ buffer was chosen since in this area macrophytes (personal observation) and macroin- vertebrates (Mancini et al., 2005) appeared influenced by land use at this scale. The index therefore represents a good surrogate of anthropogenic disturbance (Larsen et al., 2010). Here, we set the confidence level at 0.05 to attribute a significance to the covariate value.

All statistical analyses were performed with Statistica 8 Stat. Soft. and SPSS ver. 16.0.

\section{RESULTS}

We collected a total of 137 taxa (58 macrophytes +79 macroinvertebrates) (Supplementary Tab. 2), $123(50+73)$ in October 2008 and $102(42+60)$ in June 2009. We observed both abundant (e.g., Micrasema, Simuliidae, Potamogeton pectinatus and Plathypnidium riparioides in both seasons) and very rare (e.g. Habrophlebia eldae and Nostoc punctiforme in both seasons) taxa. Macrophyte and macroinvertebrate taxa showed different co-occurrence patterns, mainly showing aggregation.

As general output, the co-occurrence analyses showed the same results in both October and June. In particular, we observed a general accordance with the V-ratio results when sites without the investigated taxa were included or excluded from the analyses. Considering the $\mathrm{C}$-score, nonrandom community structures were significantly highlighted by the ff model (i.e., among different sites differences in the number of co-occurring taxa) (Tab. 3) while fe model never showed significant outputs. Our results indicate that the community is non-randomly structured, with the major part of tests indicating aggregation. In the $f f$ model the $\mathrm{C}$-score showed that there is a significant nonrandom co-occurrence in the macrophyte vs macroinvertebrate matrix than expected by chance $\left[\mathrm{P}\left(\mathrm{O}_{\mathrm{C}}<\mathrm{E}_{\mathrm{C}}\right)<0.05\right]$,
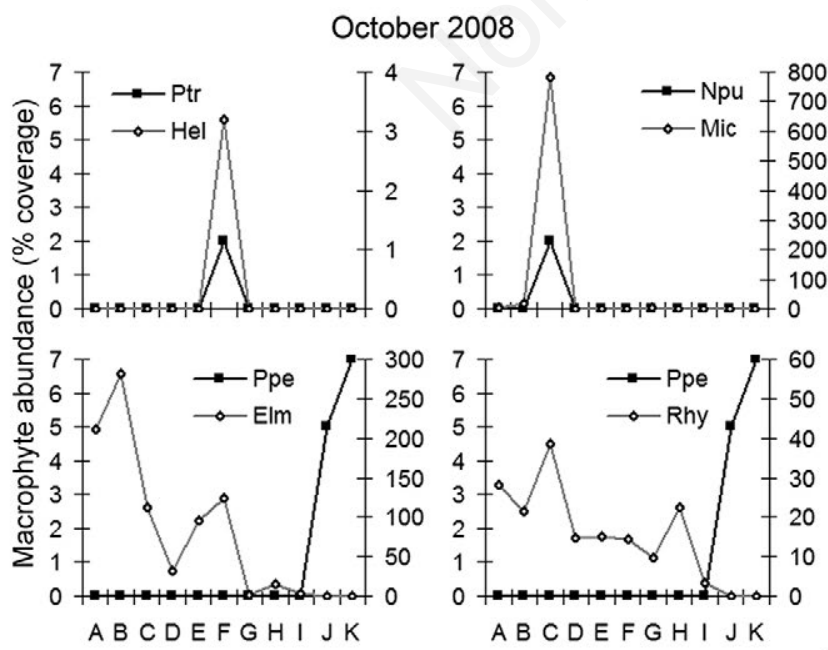

$$
\text { sampling site }
$$

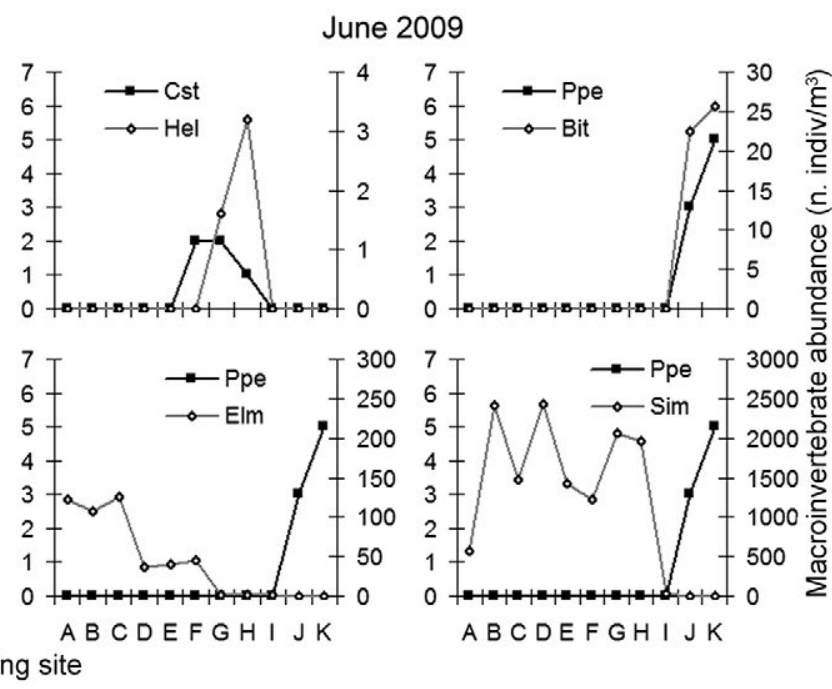

Fig. 2. Examples of positive (above) and negative (below) correlations of some taxa pairs in October 2008 and in June 2009. For the sampling sites acronyms see Fig. 1 caption. Bit, Bithynidae; Cst, Callitriche stagnalis; Elm, Elminthidae; Hel, Habrophlebia eldae; Mic, Micrasema; Npu, Nostoc punctiforme; Ppe, Potamogeton pectinatus; Ptr, Potamogeton trichoides; Rhy, Rhyacophila; Sim, Simuliidae. 


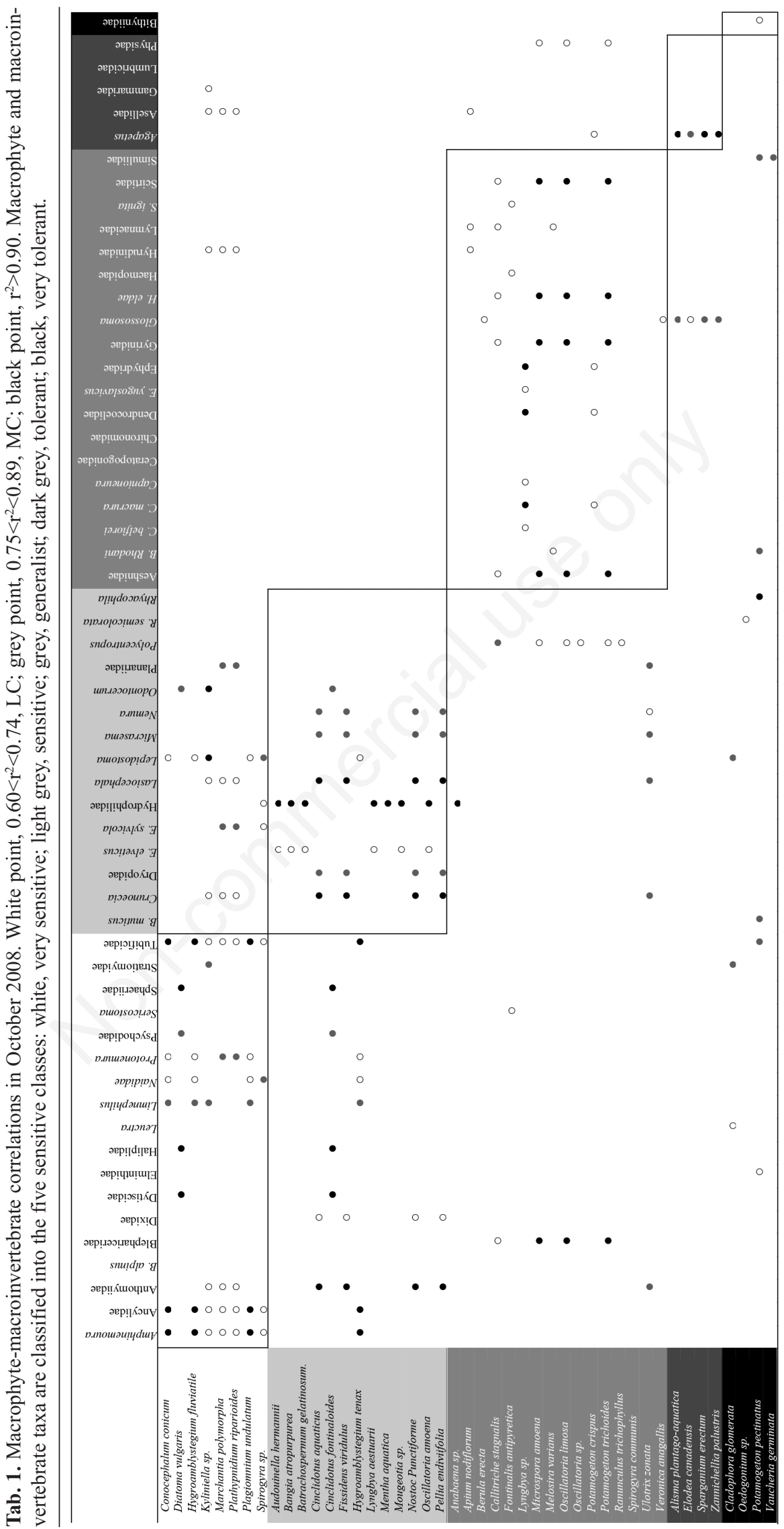


and this is confirmed by the V-ratio tests both including and excluding empty sites $\left[\mathrm{P}\left(\mathrm{O}_{\mathrm{V}}>\mathrm{E}_{\mathrm{V}}\right)<0.05\right]$.

All the correlating taxa allowed to obtain a total of 379 significantly correlating pairs. Amongst all these pairs, $83.7 \%$ of them are significantly correlated in October (Tab. 1) while $90.3 \%$ in June (Tab. 2). Finally, 9.5\% and $24.7 \%$ of the pairs were negatively correlated in October and June, respectively. Examples of correlating pairs in both sampling seasons are shown in Fig. 2.

The ANCOVA test showed a high relationships between the AI values of the sampling sites and the sensitivity class values of the correlating taxa pairs in both October $(\mathrm{F}=6.93$; $\mathrm{P}<0.05)$ and June $(\mathrm{F}=8.05 ; \mathrm{P}<0.05)($ Fig. 3$)$.

\section{DISCUSSION}

The first result of our study highlighted how macrophytes and macroinvertebrate taxa co-occur following a non-random model, as $\mathrm{C}$-score and V-ratio values indicated. In addition, where co-occurrence was confirmed, the used statistical tests indicated aggregation, while no significant segregation was recorded. Just in the last case, it was driven by randomness, since we observed non significant values for both $\mathrm{C}$-score for $\mathrm{O}_{\mathrm{C}}>\mathrm{E}_{\mathrm{C}}$, and V-ratio $\mathrm{O}_{\mathrm{v}}<\mathrm{E}_{\mathrm{v}}$ in segregation (Tab. 3). Therefore, it was possible to observe some kinds of aggregative significant relationships between macrophyte and macroinvertebrate distribution pattern along the river ecosystem.

The results of null model analysis may depend on whether non colonized sites (empty checkerboard units) are included in or excluded from the input matrices (Gotelli and Rohde, 2002). As for the C-score, our findings were significant only for the ff model, while non significant for the $f e$ one. This result suggest that empty sites have same kind of ecological meaning and they ought to be considered as not exploitable. Indeed, when empty sites are considered random absences, the test did not restitute any significant outputs. Additionally, inclusion or exclusion of checkerboard units did not affect values of V-ratio. These results agree with findings of Krasnov et al. $(2006,2010)$, who stated that outcomes of these two runs of analyses were essentially the same. Although the null model approach allows to compare the observed occurrence frequencies of running water dwelling taxa across river sites with those expected by chance, this tool cannot help for indicating the responsible mechanism for non-randomness (Rohde, 2005). However, we tried to provide some types of interpretations, aware that they may be inferred as speculative, since many synergic (and often unquantifiable) features may affect both habitat preference and river distribution of the taxa. Although different studies show that aquatic macrophytes contribute to diversify macroinvertebrate spatial niche, and consequently promote the increasing of aquatic macroinvertebrate abundances (Orth et al., 1984; Hemminga and Duarte,

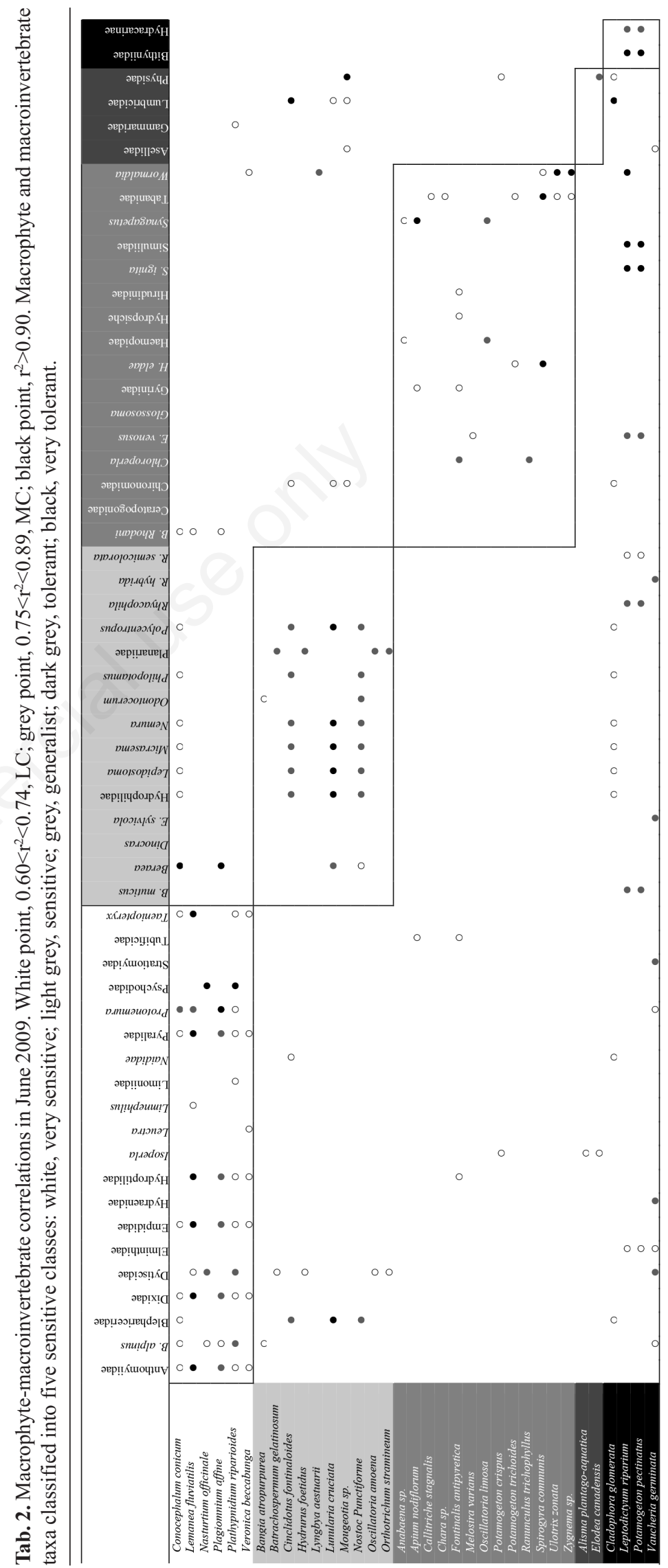


2000; Mykra et al., 2008), there is a less knowledge about the existence of significant correlations between macrophyte-macroinvertebrate taxa pairs. Anyway, among the possible explanations for correlations between macrophyte-macroinvertebrate taxa pairs, direct biotic interactions may be evoked (Hering et al., 2006). For example, Hansen et al. (2011) showed the existence of relationships between macroinvertebrate taxa and the occurrence of different macrophyte species. In particular, they showed that the increasing eutrophication due to human activities induced changes in the vegetation composition, generally rising to the proliferation of more structurally complex species and it can result in an increased abundance of macroinvertebrates. Trophic interactions may also occur between macrophytes and macroinvertebrates but, although this kind of interactions have been long evidenced from controlled experiments (Cooper et al., 1992), this sort of explanation has yet to be confirmed through field studies. Also the organism size may affect the level of the taxa assemblage. In fact, some authors have hypothesized in some studies on concordance (Allen et al., 1999; Paszkowski and Tonn, 2000) that a strong degree of cooccurrence should occur among taxa of similar size. However, findings on specific co-occurring plant-animal pair are completely missing. Another interpretation may be provided. Our results support the idea that the observed

Tab. 3. Summary of the null model analyses of co-occurrence through sites using the indices C-score and V-ratio: $\mathrm{O}<\mathrm{E}$, observed value of the index was significantly lower than the expected by chance $(\mathrm{P}<0.05) ; \mathrm{O}>\mathrm{E}$, observed value of the index was significantly greater than the expected by chance $(\mathrm{P}<0.05)$. Significant probability values are underlined. The taxon numbers are reported within parentheses.

\begin{tabular}{llllllll}
\hline \multicolumn{3}{c}{ C-score } & \multicolumn{3}{c}{ V-ratio } \\
\hline October 2008 & aggregation & $f f$ & $\mathrm{p}\left(\mathrm{O}_{\mathrm{C}}<\mathrm{E}_{\mathrm{C}}\right)$ & 0.025 & WI & $\mathrm{p}\left(\mathrm{O}_{\mathrm{V}}>\mathrm{E}_{\mathrm{V}}\right)$ & $\underline{0.021}$ \\
$(123)$ & segregation & $f f$ & $\mathrm{p}\left(\mathrm{O}_{\mathrm{C}}>\mathrm{E}_{\mathrm{C}}\right)$ & 0.784 & WI & $\mathrm{p}\left(\mathrm{O}_{\mathrm{V}}<\mathrm{E}_{\mathrm{V}}\right)$ & 0.742 \\
& aggregation & $f e$ & $\mathrm{p}\left(\mathrm{O}_{\mathrm{C}}<\mathrm{E}_{\mathrm{C}}\right)$ & 0.812 & WO & $\mathrm{p}\left(\mathrm{O}_{\mathrm{V}}>\mathrm{E}_{\mathrm{V}}\right)$ & $\underline{0.015}$ \\
& segregation & $f e$ & $\mathrm{p}\left(\mathrm{O}_{\mathrm{C}}>\mathrm{E}_{\mathrm{C}}\right)$ & 0.554 & WO & $\mathrm{p}\left(\mathrm{O}_{\mathrm{V}}<\mathrm{E}_{\mathrm{V}}\right)$ & 0.543 \\
\hline June 2009 & aggregation & $f f$ & $\mathrm{p}\left(\mathrm{O}_{\mathrm{C}}<\mathrm{E}_{\mathrm{C}}\right)$ & 0.041 & WI & $\mathrm{p}\left(\mathrm{O}_{\mathrm{V}}>\mathrm{E}_{\mathrm{V}}\right)$ & $\underline{0.035}$ \\
$(102)$ & segregation & $f f$ & $\mathrm{p}\left(\mathrm{O}_{\mathrm{C}}>\mathrm{E}_{\mathrm{C}}\right)$ & 0.623 & WI & $\mathrm{p}\left(\mathrm{O}_{\mathrm{V}}<\mathrm{E}_{\mathrm{V}}\right)$ & 0.663 \\
& aggregation & $f e$ & $\mathrm{p}\left(\mathrm{O}_{\mathrm{C}}<\mathrm{E}_{\mathrm{C}}\right)$ & 0.758 & WO & $\mathrm{p}\left(\mathrm{O}_{\mathrm{V}}>\mathrm{E}_{\mathrm{V}}\right)$ & $\underline{0.015}$ \\
& segregation & $f e$ & $\mathrm{p}\left(\mathrm{O}_{\mathrm{C}}>\mathrm{E}_{\mathrm{C}}\right)$ & 0.887 & WO & $\mathrm{p}\left(\mathrm{O}_{\mathrm{V}}<\mathrm{E}_{\mathrm{V}}\right)$ & 0.411 \\
\hline
\end{tabular}

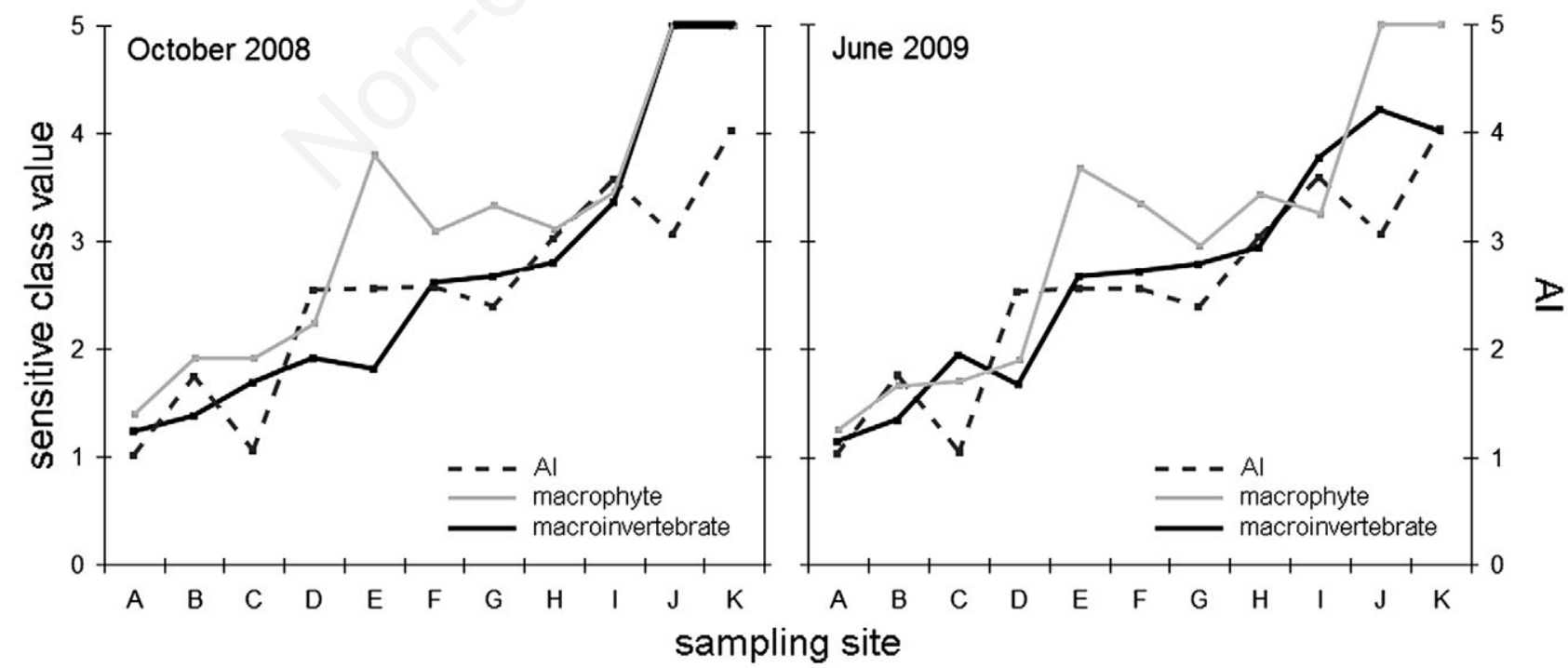

Fig. 3. Diagrams obtained by using the mean value of the sensitivity classes of the correlating pairs (macrophytes in grey, and macroinvertebrates in black), and anthropogenic index (AI, dotted line) per each site, divided per sampling session (October 2008 and June 2009). A, Filettino; B, Trevi nel Lazio; C, Jenne; D, Subiaco; E, Madonna della Pace; F, Anticoli Corrado; G, Vicovaro; H, Castel Madama; I, Tivoli; J, Lunghezza; K, Roma Nomentana. 
co-occurrence can be justified also by different types of relation occurring between single pairs of macrophytes and macroinvertebrates. For example, the use of macrophytes by macroinvertebrates can be as a refuge to escape predators, or to ambush its prey, or to direct trophic relationships related to species of herbivorous macroinvertebrates (Hansen et al., 2011).

Besides the relevant ecological issues discussed above, some applicative aspects may be argued. Specifically, the classification of the correlating taxa within the 5 sensitivity classes contributed to highlight how plants and animals may provide similar information on the human alteration grade of the watercourse. This statement was supported by the analysis of covariance outputs which showed the relationship between the anthropogenic index (as a descriptor of the human alteration) and the mean sensitivity class values along the whole river.

\section{CONCLUSIONS}

Our study demonstrates the existence of several correlations between macrophyte and macroinvertebrate taxa. It allows us to highlight different macrophytemacroinvertebrate pairs co-occurring into freshwater ecosystems, and how these pairs are linked to the human alterations. It points out the potentialities in using few taxa to perform an assessment of the running water quality. This may be realizable when the specific pairs are considered as representatives of the entire habitat status.

Clearly, authors are aware that i) this study was conducted on only one watercourse and ii) macroinvertebrate taxa were identified mainly to genus and family levels, the latter topic being the one of the most issue of concern in the riverine quality assessment (since no guides exist in literature for the invertebrate species identification). Indeed, as for the macroinvertebrate taxonomic level, a more detailed macroinvertebrate identification can strengthen obtained results. Only performing further studies (increasing the sampling sites number) we may provide strong statistical outputs helping to detect the co-occurring pairs.

Once solved these problem of the sampling sites number, our findings could be used as a new monitoring tool. The latter represents an investigation approach easy in the application, feasible and rapid in the execution, and within the WFD freshwater management policies. In addition, a such tool does not need a detailed taxonomical expertise since its applicability is restricted only to the few taxa indicated as representatives of a certain water quality condition.

\section{ACKNOWLEDGMENTS}

We are indebted to Dr. Sara Bisceglie, Dr. Valeria Ginepri, Dr. Giovanni Salerno, and Dr. Giorgio Pace, for their help during the field sampling.

\section{REFERENCES}

AFNOR, 2003. [Qualité de l'eau: détermination de l'indice biologique macrophytique en riviére (IBMR)].[Document in French]. Document no. NF T 90-395. AFNOR: 28 pp.

Aleffi M, Tacchi R, Cortini Pedrotti C, 2008. Check-list of the hornworts, liverworts and mosses of Italy. Bocconea 22:1-256.

Allen AP, Whittier TR, Larsen DP, Kaufman PR, O'Connor RJ, Hughes RM, Stemberger RS, Dixit SS, Brinkhurst RO, Herlihy AT, Paulsen RG, 1999. Concordance of taxonomic richness patterns across multiple assemblages: effects of scale, body size and land use. Can. J. Fish. Aquat. Sci. 56:2029-2040.

APAT, 2007. [Protocollo di campionamento e analisi per le macrofite delle acque correnti].[Document in Italian]. CISBA: $20 \mathrm{pp}$.

Belfiore C, 1983. [Ephemeroptera. Guida per il riconoscimento delle specie animali delle acque interne italiane].[Book in Italian]. Consiglio Nazionale delle Ricerche: 113 pp.

Bourrelly $\mathrm{P}, 1981$. [Les algues d'eau douce. Initiation à la systématique, 2. Les algues jaunes et brunes. Chrysophycées, Phéophycées, Xanthophycées et Diatomées].[Book in French]. Boubée et Cie: 438 pp.

Bourrelly P, 1985. [Les algues d'eau douce. Initiation à la systématique, 3. Les algues bleues et rouge]. Boubée et Cie: $512 \mathrm{pp}$.

Bourrelly P, 1990. [Les algues d'eau douce. Initiation à la systématique, 1. Les algues vertes].[Book in French]. Boubée et Cie: 572 pp.

Braun-Blanquet J, 1964. [Pflanzensoziologie. Grundzuge der Vegetationskunde].[Book in German]. Springer: 865 pp.

Buffagni A, Erba S, Birk S, Cazzola M, Feld C, Ofenböck T, Murray-Bligh J, Furse MT, Clarke R, Hering D, Soszka H, van de Bund W, 2005. Towards European intercalibration for the water framework directive: procedures and examples for different river types from the E.C. project STAR. 11th STAR deliverable, STAR Contract No: EVK1- CT 200100089. Quaderni Istituto di Ricerca sulle Acque 123, Italy.

Campaioli S, Ghetti PF, Minelli A, Ruffo S, 1999. [Manuale per il riconoscimento dei macroinvertebrati delle acque dolci Italiane].[Book in Italian]. Provincia autonoma di Trento: 484 pp.

Ceschin S, Zuccarello V, Caneva G, 2010. Role of macrophyte communities as bioindicators of water quality: application on the Tiber River basin (Italy). Plant Biosyst. 144:528-536.

CNR-IRSA, 2007. Macroinvertebrati acquatici e Direttiva 2000/60/EC (WFD). Consiglio Nazionale delle Ricerche: $118 \mathrm{pp}$.

Colwell RK, Winkler DW, 1984. A null model for null models in biogeography. In: Ecological Communities: Conceptual Issues and the Evidence, p. 344-359. In: (D.L. Strong Jr., D. Simberloff, L.G. Abele, A.B. Thistle (eds.), Princeton University Press, Princeton.

Consiglio C, 1980. [Plecoptera. Guida per il riconoscimento delle specie animali delle acque interne Italiane].[Book in Italian]. Consiglio Nazionale delle Ricerche: 68 pp.

Conti F, Abbate G, Alessandrini A, Blasi C, 2005. An annotated checklist of Italian vascular flora. Palombi Editore: $428 \mathrm{pp}$.

Cooper SD, Walde SJ, Peckarsky BL, 1992. Prey exchange rates and the impact of predators on prey populations in streams. Ecology 71:1503-1514.

Cortini Pedrotti C, 2001. [Flora dei muschi d'Italia. Sphagnop- 
sida, Andreaeopsida, Bryopsida (I parte)].[Book in Italian]. Antonio Delfino Editore: $817 \mathrm{pp}$.

Cortini Pedrotti C, 2005. [Flora dei muschi d'Italia. Bryopsida (II parte)].[Book in Italian]. Antonio Delfino Editore: 432 pp.

Dörr AJM, Elia AC, Rodolfi M, Garzoli L, Picco AM, D’Amen M, Scalici M, 2012. A model of co-occurrence: segregation and aggregation patterns in the mycoflora of the crayfish Procambarus clarkii in Lake Trasimeno (central Italy). J. Limnol. 71:135-143.

Dudgeon D, Arthington AH, Gessner MO, Kawabata ZI, Knowler DJ, Leveque C, Naiman RJ, Prieur-Richard AH, Soto D, Stiassny MLJ, Sullivan CA, 2006. Freshwater biodiversity: importance, threats, status and conservation challenges. Biol. Rev. 81:163-182.

Dynesius M, Nilsson C, 1994. Fragmentation and flow regulation of river systems in the northern third of the world. Science 266:753-762.

European council, 2000. establishing a Framework for Community Action in the field of Water Policy. Directive 2000/60/EC.

Ettl H, Gartner G, 1995. [Syllabus der Boden-, Luft- und Flechtenalgen].[Book in German]. Gustav Fischer Verlag: 729 pp.

Gotelli NJ, 2000. Null model analysis of species cooccurrence patterns. Ecology 81:2606-2621.

Gotelli NJ, Graves GC, 1996. Null models in ecology. Smithsonian Institution Press: 368 pp.

Gotelli NJ, Entsminger GL, 2001. Swap and fill algorithms in null model analysis: rethinking the Knight's Tour. Oecologia 129:281-291.

Gotelli NJ, McCabe DJ, 2002. Species co-occurrence: a metaanalysis of J.M. Diamond's assembly rules model. Ecology 83:2091-2096.

Gotelli NJ, Rohde K, 2002. Co-occurrence of ectoparasites of marine fishes: a null model analysis. Ecol. Lett. 5:86-94.

Hansen JP, Wikström SA, Axemar H, Kautsky L, 2011. Distribution differences and active habitat choices of invertebrates between macrophytes of different morphological complexity. Aquat. Ecol. 45:11-22.

Hausdorf B, Hennig C, 2007. Null model tests of clustering of species, negative co-occurrence patterns and nestedness in meta-communities. Oikos 116:818-828.

Heino J, 2010. Are indicator groups and cross-taxon congruence useful for predicting biodiversity in aquatic ecosystems? Ecol. Indicators 10:112-117.

Hemminga MA, Duarte CM, 2000. Seagrass ecology. Cambridge University Press, Cambridge, UK: 298 pp.

Hering D, Johnson RK, Kramm S, Schmutz S, Szoszkiewicz K, Verdonschot PFM, 2006. Assessment of European streams with diatoms, macrophytes, macroinvertebrates and fish: a comparative metric-based analysis of organism response to stress. Freshwater Biol. 51:1757-1785.

Hering D, Verdonschot PFM, Moog O, Sandin L, 2004. Integrated assessment of running waters in Europe. Kluwer: 379 pp.

Hermoso V, Clavero M, Blanco-Garrido F, Prenda J, 2010. Assessing the ecological status in species-poor systems: A fishbased index for Mediterranean Rivers (Guadiana River, SW Spain). Ecol. Indicators 10:1152-1161.

Jansson R, Nilsson C, Dynesius M, Andersson E, 2000. Effects of river regulation on river-margin vegetation: a comparison of eight boreal rivers. Ecol. Appl. 10:203-224.

John DM, Whitton BA, Brook AJ, 2002. The freshwater algal flora of the British isles. Cambridge University Press: 714 pp.

Johnes JP, 1996. Evaluation and management of the impact of land use change on the nitrogen and phosphorus load delivered to surface waters: the export coefficient modelling approach. J. Hydrol. 183:323-349.

Krasnov BR, Matthee S, Lareschi M, Korallo-Vinarskaya NP, Vinarski MP, 2010. Co-occurrence of ectoparasites on rodent hosts: null model analyses of data from three continents. Oikos 119:120-128.

Krasnov BR, Stanko M, Morand S, 2006. Are ectoparasite communities structured? Species co-occurrence, temporal variation and null models. J. Anim. Ecol. 75:1330-1339.

Larsen S, Mancini A, Pace G, Scalici M, Tancioni L, 2012. Weak concordance in fish and macroinvertebrates in Mediterranean streams. PLoS One 7:e51115.

Larsen S, Sorace A, Mancini L, 2010. Riparian bird communities as indicators of human impacts along Mediterranean streams. Environ. Manage. 45:261-273.

Lehsten V, Harmand P, 2006. Null models for species co-occurrence patterns: assessing bias and minimum iteration number for the sequential swap. Ecography 29:786-792.

Lloyd NJ, MacNally R, Lake PS, 2006. Spatial scale of autocorrelation of assemblages of benthic invertebrates in two upland rivers in South-Eastern Australia and its implications for biomonitoring and impact assessment in streams. Environ. Monit. Assess. 115:69-85.

Malmqvist B, Rundle S, 2002. Threats to the running water ecosystems of the world. Environ. Conserv. 29:134-153.

Mancini L, Formichetti P, Anselmo A, Tancioni L, Marchini S, 2005. Biological quality of running waters in protected areas: the influence of size and land use. Biodiv. Conserv. 14:351-364.

Manfrin A, Larsen S, Traversetti L, Pace G, Scalici M, 2013. Longitudinal variation of macroinvertebrate communities in a Mediterranean river subjected to multiple anthropogenic stressors. Int. Rev. Hydrobiol. 98:155-164.

Mazzini I, Ceschin S, Abati S, Gliozzi E, Piccari F, Rossi A, 2014. Ostracod communities associated to aquatic macrophytes in an urban park in Rome, Italy. Int. Rev. Hydrobiol. DOI 10.1002/iroh.201301728.

McCoy ED Jr, Heck KL, 1987. Some observations on the use of taxonomic similarity in large-scale biogeography. J. Biogeogr. 14:79-87.

Moretti G, 1983. [Trichoptera. Guida per il riconoscimento delle specie animali delle acque interne Italiane].[Book in Italian]. Consiglio Nazionale delle Ricerche: 155 pp.

Mykra H, Aroviita J, Hämäläinen H, Kotanen J, Vuori KM, Muotka T, 2008. Assessing stream condition using macroinvertebrates and macrophytes: concordance of community responses to human impact. Fundam. Appl. Limnol. 172:191-203.

Orth RJ, Heck KL, van Montfrans J, 1984. Faunal communities in seagrass beds: a review of the influence of plant structure and prey characteristics on predator-prey relationships. Estuaries 7:339-350.

Pace G, Andreani P, Barile M, Buffagni A, Erba S, Mancini L, Belfiore C, 2011. Macroinvertebrate assemblages at mesohabitat scale in small sized volcanic siliceous streams of Central Italy (Mediterranean Ecoregion). Ecol. Indicators 11:688-696.

Paszkowski CA, Tonn WM, 2000. Community concordance be- 
tween the fish and aquatic birds of lakes in northern Alberta, Canada: the relative importance of environmental and biotic factors. Freshwat. Biol. 43:421-437.

Pignatti S, 1982. [Flora d'Italia].[Book in Italian]. Edagricole: $2324 \mathrm{pp}$.

Rohde K, 2005. Nonequilibrium ecology. Cambridge University Press: $236 \mathrm{pp}$.

Sanderson JG, 2000. Testing ecological patterns. Am. Sci. 88:332-339.

Sansoni G, 1988. [Atlante per il riconoscimento dei macroinvertebrati dei corsi d'acqua Italiani].[Book in Italian]. Provincia autonoma di Trento: $190 \mathrm{pp}$.

Schluter D, 1984. A variance test for detecting species associations, with some example applications. Ecology 65:998-1005.

Stone L, Roberts A, 1990. The checkerboard score and species distributions. Oecologia 85:74-79.
Tachet H, Richoux P, Bournaud M, Usseglio-Polatera P, 2002. [Invertébrés d'eau douce]. [Book in French]. CNRS: 587 pp.

Traversetti L, Scalici M, 2014. Assessing the influence of source distance and hydroecoregion on the invertebrate assemblage similarity in central Italy streams. Knowl. Manag. Aquat. Ec. 414:02.

Traversetti L, Scalici M, Ginepri V, Manfrin A, Ceschin S, 2013. Concordance between macrophytes and macroinvertebrates in Mediterranean river of central Apennine region. J. Environ. Biol. 35:497-503.

Vörösmarty CJ, Green P, Salisbury J, Lammers RB, 2000. Global water resources: vulnerability from climate change and population growth. Science 289:284-288.

Wootton JT, Parker MS, Power ME, 1996. Effects of disturbance on river food webs. Science 273:1558-1561. 